\title{
Degradation, water uptake, injectability and mechanical strength of injectable bone substitutes composed of silk fibroin and hudroxyapatite nanorods
}

\author{
Degradación, absorción, inỵectabilidad y resistencia mecánica de \\ sustitutos óseos inyectables compuestos de fibroína y nanobarras de \\ hidroxiapatita
}

Degradação, absorção, injetabilidade e resistência mecânica de substitutos ósseos injetáveis compostos de fibroína e nanobarras de hidroxiapatita

Fecha de recepción: 18 de noviembre de 2017

Fecha de aprobación: 7 de enero de 2018

Maritza Buitrago-Vásquez*

Claudia Patricia Ossa-Orozco*

\begin{abstract}
Injectable bone substitutes are generally composite materials capable of being extruded through a device; they consist of a solid phase inside a matrix that allows the easy movement of particles. Injectable bone substitutes have the advantage of allowing its application in situ without the need of invasive surgical techniques, guaranteeing a good recovery; for this reason, they are a promising alternative to replace conventional techniques to repair bone defects. Conventional techniques include the use of allografts and autografts, which often cause adverse reactions, and are disadvantageous for both the patient and the doctor. Furthermore, there are no reports regarding bone substitute development in Colombia, creating the necessity to research composite materials that could become injectable bone substitutes. In this study, we manufactured injectable bone substitutes with hydroxyapatite and calcium phosphate, which is most similar to bone tissue, and synthesized them in nanorods with shape and size similar to the natural hydroxyapatite found inside the body. Additionally, we used extracted silk fibroin from silkworm cocoons of Bombyx mori, a natural polymer of protein nature with high mechanical properties and excellent biocompatibility. For the materials manufactured, we evaluated degradation, in a simulated body fluid (SBF) at normal body temperature, water uptake, injectability and mechanical strength. The manufactured bone substitutes showed good degradation and water uptake properties, an approximate $97 \%$ injectability, and low mechanical resistance, indicating promising properties to be used as an injectable bone substitute.
\end{abstract}

Keywords: biomaterials; bone substitutes; ceramics; composite materials; polymers.

* M. Sc. Universidad de Antioquia (Medellín-Antioquia, Colombia).

** Ph. D. Universidad de Antioquia (Medellín-Antioquia, Colombia). claudia.ossa@udea.edu.co. 
Degradation, water uptake, injectability and mechanical strength of injectable bone substitutes composed of silk fibroin and hydroxuapatite nanorods

\section{Resumen}

Los sustitutos óseos inyectables son materiales compuestos que tienen la propiedad de dejarse extruir a través de un dispositivo; constan de una fase sólida inmersa en una matriz que permite el fácil movimiento del componente sólido, y tienen como ventaja permitir su aplicación in situ sin necesidad de recurrir a técnicas quirúrgicas invasivas, garantizando una buena recuperación; razón por la que son considerados una buena alternativa para reemplazar las técnicas convencionales para la reparación de defectos óseos, las cuales incluyen, principalmente, el uso de aloinjertos y autoinjertos, que generan una serie de reacciones adversas y tienen desventajas tanto para el médico como para el paciente. En Colombia no se encuentran reportes acerca del desarrollo de sustitutos óseos; esto genera la necesidad de investigar un material compuesto que tenga potencial aplicación como sustituto óseo inyectable. En la presente investigación se fabricaron sustitutos óseos de hidroxiapatita -fosfato de calcio que mayor similitud presenta con el tejido óseo-, sintetizada en nanobarras, con tamaño y forma similar a como se dispone naturalmente en el hueso; y la fibroína de seda extraída de los capullos del gusano Bombyx mori, como polímero natural de naturaleza proteica con altas propiedades mecánicas y excelente biocompatibilidad. Los materiales fabricados se caracterizaron por degradación en solución fisiológica a temperatura corporal, absorción de agua, inyectabilidad y resistencia mecánica. Los sustitutos óseos fabricados presentaron buenas propiedades de degradación y absorción, una inyectabilidad aproximada del 97 \% y baja resistencia mecánica, mostrando propiedades promisorias para usarse como sustituto óseo inyectable.

Palabras clave: biomateriales; cerámicos; materiales compuesto; polímeros; sustitutos óseos.

\section{Resumo}

Os substitutos ósseos injetáveis são materiais compostos que têm a propriedade de deixar-se extruir através de um dispositivo; constam de uma fase sólida imersa em uma matriz que permite o fácil movimento do componente sólido, e têm como vantagem permitir sua aplicação in situ sem necessidade de recorrer a técnicas cirúrgicas invasivas, garantindo uma boa recuperação; razão pela qual são considerados uma boa alternativa para substituir as técnicas convencionais para a reparação de defeitos ósseos, as quais incluem, principalmente, o uso de aloenxertos e autoenxertos, que geram uma série de reações adversas e têm desvantagens tanto para o médico como para o paciente. Na Colômbia não se encontram relatos acerca do desenvolvimento de substitutos ósseos; isto gera a necessidade de pesquisar um material composto que tenha potencial aplicação como substituto ósseo injetável. Na presente pesquisa fabricaram-se substitutos ósseos de hidroxiapatita -fosfato de cálcio que maior semelhança apresenta com o tecido ósseo-, sintetizada em nanobarras, com tamanho e forma similar àquela que se dispõe naturalmente no osso; e a fibroína de seda extraída dos casulos do bicho da seda Bombyx mori, como polímero natural de natureza proteica com altas propriedades mecânicas e excelente biocompatibilidade. Os materiais fabricados caracterizaram-se por degradação em solução fisiológica à temperatura corporal, absorção de água, injetabilidade e resistência mecânica. Os substitutos ósseos fabricados apresentaram boas propriedades de degradação e absorção, uma injetabilidade aproximada de $97 \%$ e baixa resistência mecânica, mostrando propriedades promissoras para usar-se como substituto ósseo injetável.

Palavras chave: biomateriais; cerâmicos; materiais compostos; polímeros; substitutos ósseos.

\section{Para citar este artículo:}

M. Buitrago-Vásquez, and C. P. Ossa-Orozco, "Degradation, water uptake, injectability and mechanical strength of injectable bone substitutes composed of silk fibroin and hydroxyapatite nanorods," Revista Facultad de Ingeniería, vol. 27 (48), pp. 49-60, may. 2018. 


\section{INTRODUCTION}

Worldwide, bone defects represent a common health problem, usually caused by various diseases, fractures or congenital problems that require different bone repair techniques to fix them. Currently, numerous types of grafts, classified according to their origin, are use clinically: autografts from the same patient, allografts from the same species, xenografts from other species, such as deproteinized bovine bone, and alloplastic bone substitutes that are synthetically manufactured [1-3].

Autografts have biocompatibility advantages and excellent osteogenic properties. However, they have disadvantages in terms of the extraction site, which usually is in the iliac crest or other bones such as tibia and femur; this extraction involves double surgery, increase pain, morbidity of the extraction site, and quantity of bone available according to the amount of tissue needed to correct the defect $[1,2]$. Allografts provide biocompatibility properties, different reconstruction options, and replacement of bone parts. However, despite being a good option, they represent a structural failure risk compared to autografts, since the mechanical and biological properties of the bone change depending on the location in the body. Additionally, allografts are subjected to processes and treatments such as radiation and lyophilization to reduce the risk of disease transmission and immunological disorders, although they are not always completely successful $[1,3]$. In contrast, xenografts have had good results in small portions of bone, although their main disadvantage is the risk of immunological reactions, and transmission of viral and infectious diseases [4-7].

Alloplastic bone substitutes have been widely researched and are becoming more frequently used since they offer multiple options and compositions with which they can be manufactured. Bioceramic bone substitutes, such as calcium phosphates, are the most researched due to their good biocompatibility, osteoconduction and osseointegration properties $[4,8$, 9]; they are usually manufactured in rigid forms, which prevents the filling of cavities with complex shapes. Furthermore, injectable bone substitutes have been studied because they offer many clinical application benefits, primarily in surgeries, to correct bone defects and fill cavities; they represent an easy method at the surgical level and are less traumatic for the patients [10]. Injectable systems are usually composite materials, manufactured with calcium phosphates and polymers that seek to have a composition similar to the bone $[11,12]$.

Hydroxyapatite (HA) is a calcium phosphate like the mineral found in bones. It has good polymer affinity and can provide excellent proliferation and cell adhesion when synthesized and used at the nanoscale (nHA). These characteristics make HA an appropriate material to develop an injectable system [13]. Silk is a polymeric material produced by insects such as spiders and silkworms like Bombyx mori; it is composed of two proteins: sericin and fibroin. Using silk fibroin (SF) as a biomaterial began in recent decades due to its good mechanical and biological properties; its excellent biocompatibility is due to its protein nature since proteins are present in living tissues. As a result, SF has been implemented in various applications such as hydrogels, films, macroparticles, scaffolds and injectable systems $[12,14,15]$. This work aims to develop an injectable bone substitute composed of hydroxyapatite nanorods (nHA) and silk fibroin produced by $B$. mori, and evaluate its degradation, water uptake, mechanical resistance and injectability, which will allow assessing whether it is possible to use it as an osseous substitute.

\section{Materials and Methods}

\section{A. Synthesis and characterization of hydroxyapatite nanorods}

HA nanorods (nHA) were synthesized from the following chemical reaction (1):

\section{$10 \mathrm{Ca}(\mathrm{NO} 3) 24 \mathrm{H} 2 \mathrm{O}+6(\mathrm{NH} 4) 2 \mathrm{HPO} 4+8 \mathrm{NH} 4 \mathrm{OH} \rightarrow \mathrm{Ca} 10(\mathrm{PO} 4) 6(\mathrm{OH}) 2+$ $20 \mathrm{NH} 4 \mathrm{NO} 2+46 \mathrm{H} 2$}

The $\mathrm{Ca}\left(\mathrm{NO}_{3}\right)_{2} 4 \mathrm{H}_{2} \mathrm{O}$ and $\left(\mathrm{NH}_{4}\right)_{2} \mathrm{HPO}_{4}$ were prepared in aqueous solutions of $0.5 \mathrm{M}$ and $0.3 \mathrm{M}$, respectively, to guarantee a stoichiometric ratio of $\mathrm{Ca} / \mathrm{P}=1.67$.
We adjusted the $\mathrm{pH}$ to 10 with ammoniacal solution, and later combined the solutions by dripping with magnetic stirring at a controlled speed. We placed 
Degradation, water uptake, injectability and mechanical strength of injectable bone substitutes composed of silk fibroin and hydroxyapatite nanorods

the final solution in a hermetic Teflon autoclave to undergo hydrothermal treatment for $24 \mathrm{~h}$ at $180{ }^{\circ} \mathrm{C}$, and once the process finished, we cooled down the vessel at room temperature. We washed the solution with distilled water until reaching a neutral $\mathrm{pH}$ and dried it for $24 \mathrm{~h}$ at $80{ }^{\circ} \mathrm{C}$ to obtain a fine powder [16].

We used transmission electron microscopy with field emission (FE-SEM) and transmission electron microscopy (TEM) to observe the morphology of the particles, using the JEOL JSM 7100 and TECNAI F20 SUPER TWIN TMP microscopes, respectively. We evaluated phase stabilization corresponding to HA and its crystallinity through X-ray diffraction (XRD) in a Rigaku X-ray equipment provided with a $\mathrm{Cu}$ source and an angle $2 \theta$ between $5^{\circ}$ and $60^{\circ}$. We obtained the $\mathrm{Ca} / \mathrm{P}$ ratio by $\mathrm{X}$-ray Fluorescence (XRF) using a PANalytical minipal 2 spectrometer with dispersive energy and direct excitation.

\section{B. Fibroin (SF) preparation and characterization}

To obtain the fibroin, first, we prepared the silkworm cocoons, which we cut into small pieces and then submerged them in an aqueous solution $0.1 \% \mathrm{wt} / \mathrm{v}$ of $\mathrm{NaCO}_{3}$ at $80^{\circ} \mathrm{C}$ for one hour under magnetic stirring to remove the sericin $[17,18]$. Subsequently, we washed the SF extract with distilled water and dissolved it in a solution of $\mathrm{CaCl}_{2}, \mathrm{H}_{2} \mathrm{O}$ and $\mathrm{CH}_{3} \mathrm{CH}_{2} \mathrm{OH}$ 1:8:2 molar between $45{ }^{\circ} \mathrm{C}$ and $55{ }^{\circ} \mathrm{C}$ for one hour [19-21]. The solution underwent a dialysis process, with distilled water in cellulose acetate membranes for five days to remove the inorganic salts remaining from the previous processes. We calculated the concentration of the final solution from the weight of the solid after the solution dried completely [21]. We characterized the SF through a Fourier Transform (FTIR-ATR) spectroscopy in a SHIMADZU IR TRACER 100 device and through polyacrylamide gel electrophoresis to calculate the molecular weight. The gel concentration was $4 \%$ for the gel separator and $10 \%$ for the concentrator gel; additionally, we used a Thermo Scientific protein marker of 10 to $180 \mathrm{kDa}$. The test was carried out in a MINI PROTEAN electrophoresis cell with an initial run of $80 \mathrm{~V}$ for $30 \mathrm{~min}$ and a final run of $120 \mathrm{~V}$ for $120 \mathrm{~min}$.

\section{Preparation of injectable bone substitutes SF/ $n \boldsymbol{n} \boldsymbol{A}$}

We used two concentrations ( $1 \%$ and $1.5 \%)$ of the SF solution from a concentrated solution of $2.5 \%$; we mixed the solutions with glutaraldehyde (GTA) as a crosslinking agent, and subsequently, we added the $\mathrm{nHA}$ at $60 \% \mathrm{wt} / \mathrm{v}$ slowly under magnetic stirring for a period of one to two hours or until the material became viscous. We left the final mixture standing for $24 \mathrm{~h}$ to complete the crosslinking and to stabilize the polymer before using it [22-25].

\section{In vitro degradation and water uptake}

We enclosed the SF/nHA bone substitutes in cylindrical molds of $13.55 \mathrm{~mm}$ in diameter and 16 $\mathrm{mm}$ in height to give them a defined shape, and dried them for three hours at $90{ }^{\circ} \mathrm{C}$. For the degradation test we considered a modification of the ASTM F1634-95 standard [26], hence, the substitutes were immersed in a solution of concentrated ionic salts or SBF with a $\mathrm{pH}$ of 7, following the protocol described by Kokubo and Takadama [27]; afterwards, the samples were incubated at $37^{\circ} \mathrm{C}$ for 28 days. After we removed the samples from the solution and dried them as described above, we measured degradation by recording their mass on days $0,1,7,14,21$, and 28 , to observe the weight loss trend and calculate the percentage of degradation using equation (2). It should be noted that day 0 is the start day, thus the mass corresponds to the initial mass of the sample.

$$
\% D=(M o-M t / M o) * 100
$$

Where $\mathrm{M}_{0}$ is the mass of the substitute on day 0 or the initial mass, and $\mathrm{M}_{\mathrm{t}}$ is the mass of the substitute on days $1,7,14,21$ or 28 . We evaluated water uptake through an in vitro degradation test on the same days (1, 7, 14, 21 and 28), following Silva et al. [28] and Oliveira et al. [29]. We measured the mass of the substitute immediately after we removed the sample from the SBF and before drying it, and calculated the water uptake percentage using equation (3).

$$
\% A b s=(M H-M o / M o) * 100
$$

Where $\mathrm{M}_{\mathrm{H}}$ is the mass of the wet sample after being removed from the SBF on days 1, 7, 14, 21 and 28, and $\mathrm{M}_{0}$ is the initial mass or mass taken on day 0 . 


\section{E. Injectability and mechanical strength}

To determine the force required to extrude the material through a device, we used a universal DIGIMESS testing machine with a load cell of $4900 \mathrm{~N}$ and a minimum speed of $5 \mathrm{~mm} / \mathrm{min}$. We placed the material in a $10 \mathrm{ml}$ syringe with a 14 Gauge hypodermic needle and an inner diameter of $2.15 \mathrm{~mm}$. The maximum force was $300 \mathrm{~N}$ with a speed of $10 \mathrm{~mm} / \mathrm{min}$. The universal machine was equipped with a compression plate on top and a handle at the bottom to hold the syringe. The force was applied vertically on the plate until the material was completely extruded or until the force reached $300 \mathrm{~N}$, taking into account other protocols [30-32]. We calculated the injectability percentage using equation (4).

$$
\% I=(\text { Mext } / M o) * 100
$$

Where $\mathrm{M}_{\mathrm{ext}}$ is the mass extruded by the syringe, and $\mathrm{M}_{0}$ is the mass of the material in the syringe before injection.

We measured mechanical strength through a compression test, modifying the ASTM C 1424-04 standard and using the same DIGIMESS universal machine described in the injectability test [33]. The test pieces were made in cylindrical molds of approximately $18.4 \mathrm{~mm}$ in height and $19.2 \mathrm{~mm}$ in diameter.

\section{RESUlTS AND DISCUSSION}

\section{A. Characterization of nanohydroxyapatite $\mathrm{nHA}$}

Figure 1 shows the FE-SEM and TEM micrographs of the nHA particles obtained by the precipitation and hydrothermal treatments. The image analysis processing software allowed observing the nanorods morphology. The average values obtained were $246.13 \pm 61.99 \mathrm{~nm}$ in length and $39.93 \pm 8.37 \mathrm{~nm}$ in diameter. These results agree with other authors who synthesized HA nanorods through similar methods [34]. The TEM image (Fig. 1b) confirms the results, showing that the nanorods synthesized with agglomerates have characteristics of nanometer-scale materials; the morphology is comparable with that reported by other authors for powders manufactured using similar methods [35-37].

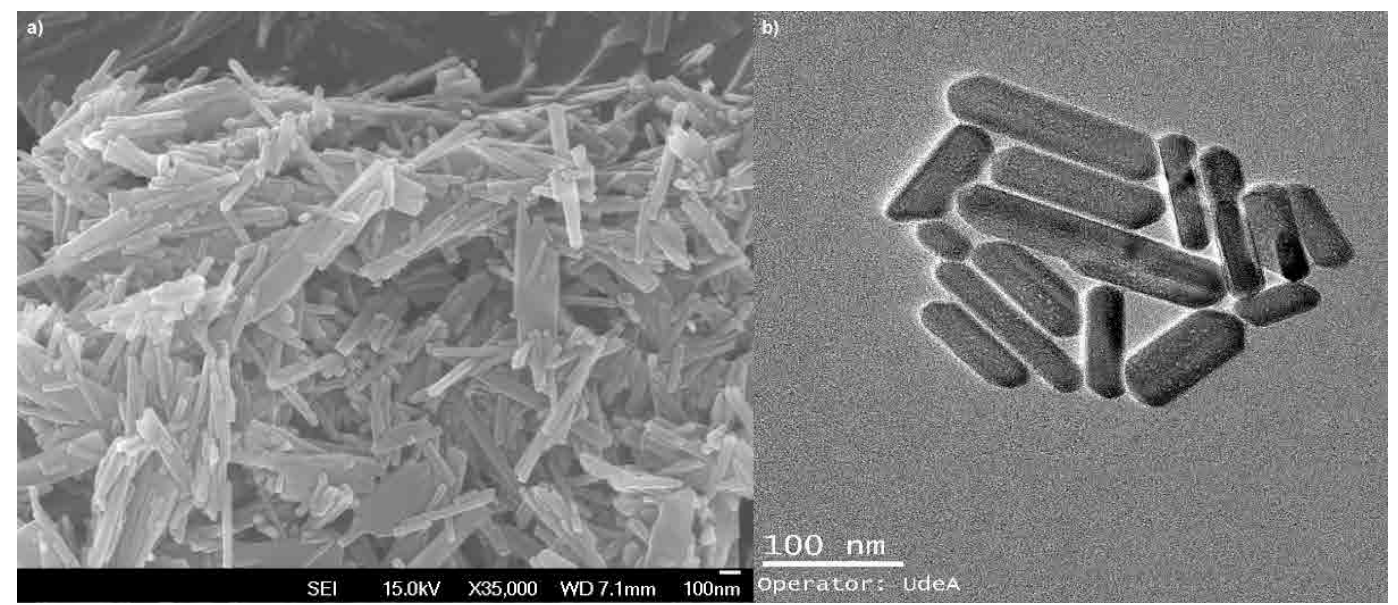

Fig. 1. Micrographs of nHA powder. a) FE-SEM and b) TEM.

The XRD pattern registered for the nHA powder obtained (Fig. 2) can be compared with a typical HA (JCPD 72-1243), displaying the main peaks at $2 \theta$ $31.9^{\circ}, 32.2^{\circ}$ and $33.1^{\circ}$, and secondary peaks at $2 \theta 26^{\circ}$, $34.3^{\circ}, 40^{\circ}, 46.9^{\circ}, 49.7^{\circ}$ and $53.4^{\circ}$, in addition to other peaks of lower intensity, all corresponding to HA.
Peaks corresponding to the stabilized phase of other calcium phosphates were not evident, highlighting that the intensity and narrowing of the peaks shows that the material has good crystallinity properties, making it suitable for using it as a biomaterial according to ASTM F1185-03 [38-40]. 


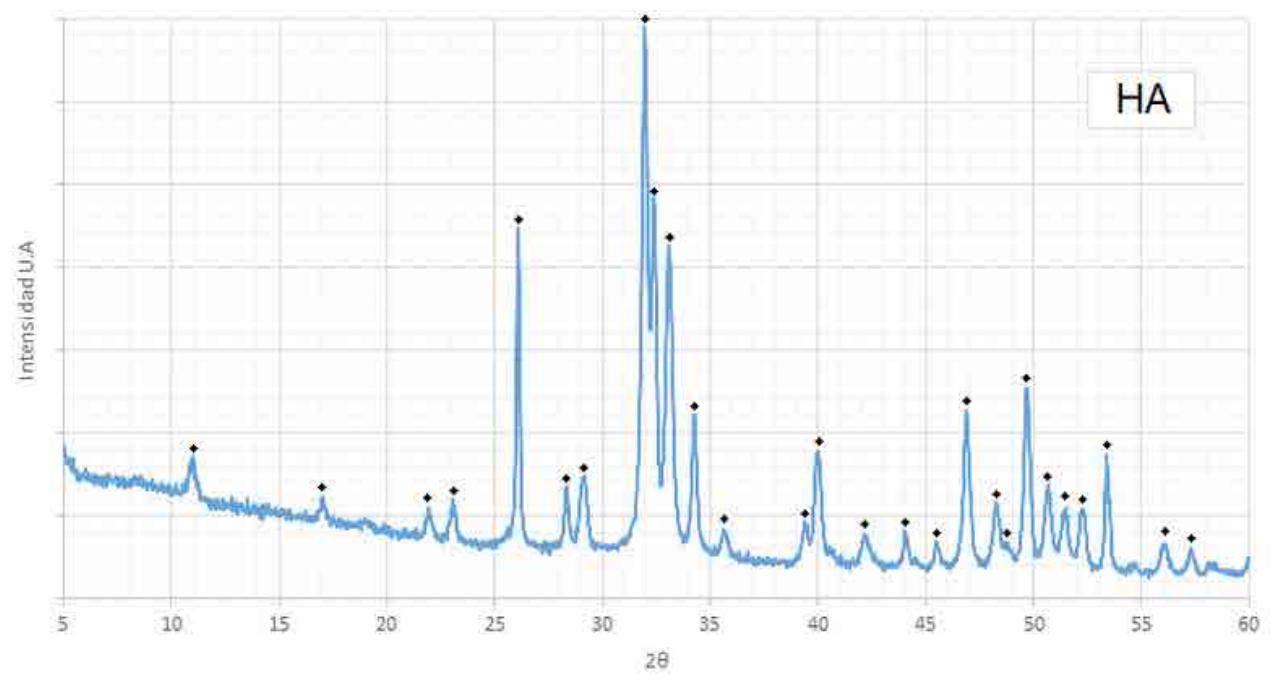

Fig. 2. Diffractogram of the HA powder obtained.

The XRF test results for the HA powder yielded a $\mathrm{Ca} / \mathrm{P}$ ratio of 1.67 , a value that corresponds to a stoichiometric HA, suitable for developing composite material; thus, we conclude that the material obtained by the methodology described here, not only favors the formation of nanorods and phase stabilization, but also guarantees an adequate molar ratio, which is reflected in the results and therefore is apt to be used as a biomaterial.

\section{B. Characterization of fibroin}

The SF structure consists of a chain of repeating amino acids, which are mainly glycine, alanine and serine, thus giving different types of molecular structures known as $\alpha$-helix and $\beta$-sheets, also called silk I and silk II, respectively [41]. In the infrared spectroscopy
(IR) spectrum for the fibroin obtained, the region of interest is located between 1000 and $1800 \mathrm{~cm}^{-1}$ (Fig. 3 ), since this area is where the amides characteristics of the material are displayed, and depending on the value of the vibration bands, it can indicate whether they correspond to silk I or silk II. The bands at 1651, 1514 and $1234 \mathrm{~cm}^{-1}$ in the spectrum refer to amides I, II and III, respectively, for silk I ( $\alpha$-helix); and at approximately 1639 and $1529 \mathrm{~cm}^{-1}$, the vibration bands of amides I and II corresponds to silk II ( $\beta$-sheets). The presence of amide III is not clearly observed for this structure, but it is possible that the bands overlap since they are usually very close to amide III of silk I. In addition, the vibration band looks wide possibly concealing the band corresponding to the amide III of silk II, concluding that this band can be present between 1230 and $1270 \mathrm{~cm}^{-1}[28,42,43]$. 


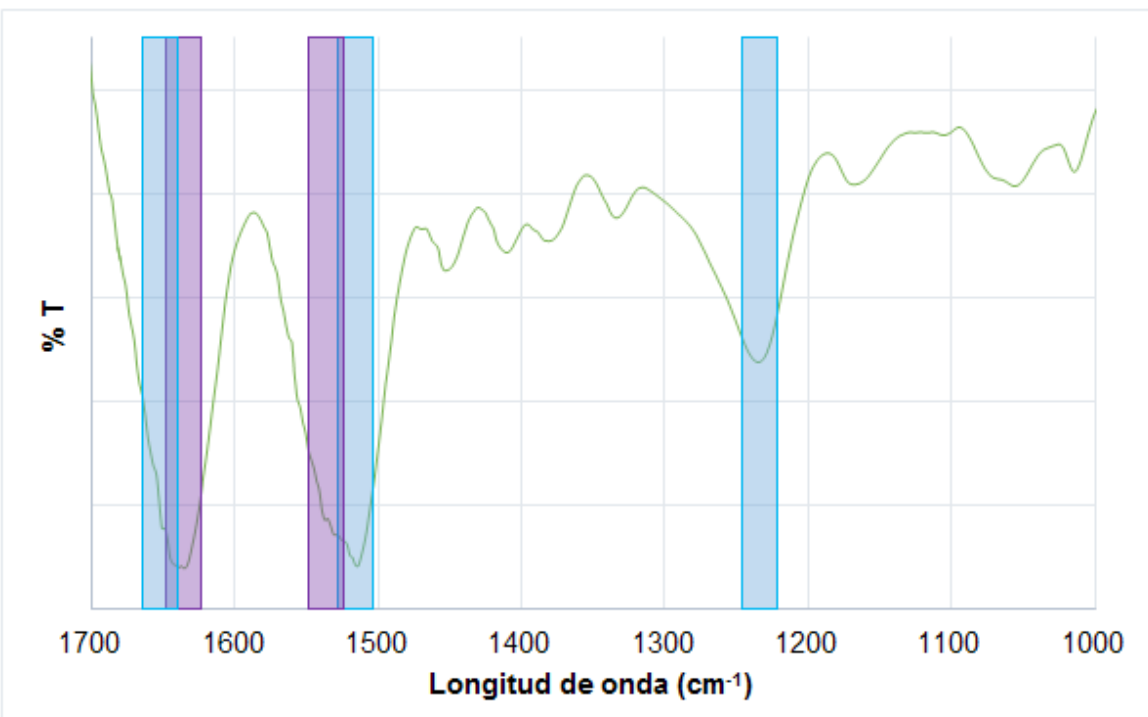

Fig. 3. IR spectrum for the SF obtained. Amides I and II for $\beta$-sheets structure in light gray, and amides I, II and III for $\alpha$-helix structure in dark gray.

Fibroin is a large protein that has two molecular chains, a heavy one reported between 250 and 390 $\mathrm{kDa}$ and a light one reported between 25 and $29 \mathrm{kDa}$ [28]. After the electrophoresis test (Figure not shown), the gel revealed a thick band at $180 \mathrm{kDa}$, which may correspond to the heavy chain, suggesting that this chain could have a higher molecular weight, due to the thickness of the band. A less noticeable band was observed at approximately $25 \mathrm{kDa}$, which is attributed to the light chain of fibroin, thus reaffirming the high possibility that the band at $180 \mathrm{kDa}$ corresponds to the heavy chain. Other authors suggest that the molecular weight distributions between 25 and $120 \mathrm{kDa}$ in revealed polyacrylamide gels are correct for fibroin, since factors such as fibroin extraction conditions, reagents and temperature may influence the results directly [44].

\section{Characterization of SF/nHA substitutes}

1) In vitro degradation and water uptake: The resulting degradation percentages (Fig. $4 \mathrm{a}$ and 4b) show the lack of similar patterns among the compositions, indicating the absence of correlation between fibroin concentrations and degradation. The replicates (M1, M2 and M3) for each composition exhibited a similar degradation pattern, behavior that can be explained considering the we used the same batch of fibroin for each replicate. Although we used the same method to extract the fibroin, the differences may be explained by the concentration of the final solution after dialysis, thus showing the influence of the fibroin extraction lot on the characteristics of the bone substitute. In general, the results show that bone substitutes have low degradation percentages that are unaffected by the amount of fibroin used, since all materials contained $60 \% \mathrm{nHA}$, which is responsible for the slow degradation due to its physicochemical properties, composition and structure. The dissolution mechanism of HA in composite materials occurs mainly through ion exchange with the medium. The nHA used in the bone substitutes has the phase and the $\mathrm{Ca} / \mathrm{P}$ ratio of HA stoichiometric, making it responsible for the stability of the material and its low degradation percentages, which, being less than $30 \%$ after four weeks, indicates that it could allow tissue regeneration after implantation $[6,45]$. 
Degradation, water uptake, injectability and mechanical strength of injectable bone substitutes composed of silk fibroin and hụdroxyapatite nanorods

a)

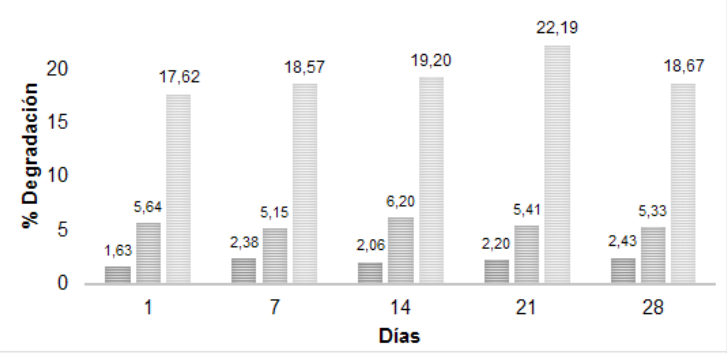

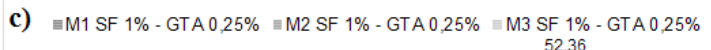

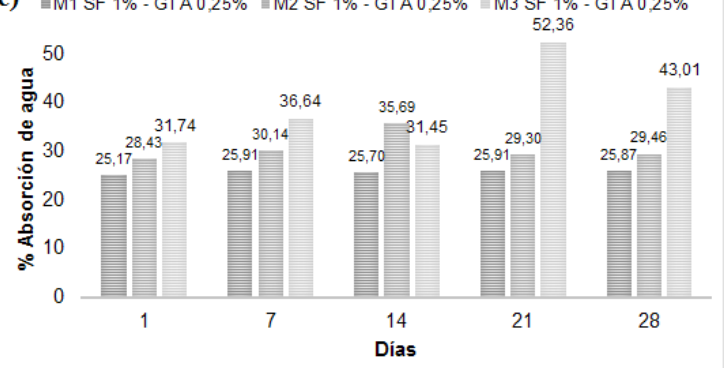

b)

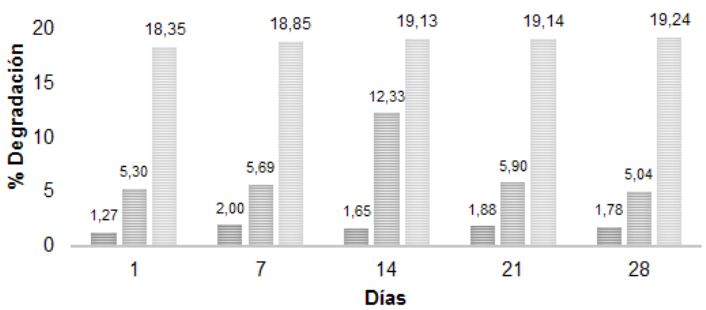

d) $=M 1$ SF $1,5 \%$ - GTA $0,25 \%=M 2$ SF $1,5 \%$ - GTA $0,25 \%=M 3$ SF $1,5 \%$ - GTA $0,25 \%$

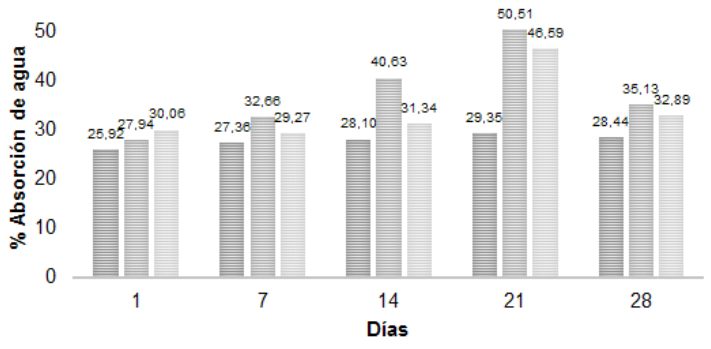

Fig. 4. a, b) Degradation percentages; c, d) Water uptake percentages of injectable bone substitutes SF/nHA.

Water uptake is an important property that provides information regarding the exchange and diffusion of nutrients between the material and the environment, and the diffusion of waste [28]. The resulting water uptake values (Fig. 4c and 4d) were similar among replicates, as in the degradation test, noting the lack of a direct relationship between the concentration of fibroin and the water uptake. Fibroin is a hydrophobic polymer, while HA is hydrophilic [46, 47]. Although there is no point of comparison to determine whether these values are favorable or not, a high percentage water uptake is not beneficial in injectable bone substitutes, since it directly influences their degradation by collapsing the material, mainly when it is hydrophilic, as is the case of HA; in this case, the addition of small percentages of fibroin allows a moderate water uptake due to its hydrophobic nature $[46,48]$. Additionally, the porosity of the material may play an important role in the water uptake; the substitute is considered a non-porous material, but the ionic exchange with the medium provokes its degradation and the formation of micro-porosities that allow water uptake $[6,49]$. Furthermore, our water uptake values were lower compared to those obtained in other studies on materials made of fibroin and calcium phosphates, which are usually between $42 \%$ and $70 \%[46,47]$.

2) Injectability and mechanical strength: The injectability test aims to demonstrate that fibroin acts as a vehicle that facilitates the movement of solid particles, which are $60 \%$ of nHA, so that the material can be manually extruded. We chose a maximum limit of $300 \mathrm{~N}$, since research on injectable materials show maximum forces between 100 and $300 \mathrm{~N}$, which correspond to the range of force that can be manually applied at the time of injection without the help of external mechanical forces [30, 31, 50]. The injectability test curve (Fig. 5a) shows that, with a fibroin concentration of $1 \%$, an initial force is required to start the injection process, though the force decreases as the material is extruded out of the syringe; in contrast, with a concentration of $1.5 \%$ the force increases gradually as the material is extruded; neither case required greater forces. The difference in both curves may be due to the confinement of the material inside the syringe, since air bubbles could have been left inside; however, these differences are not considered important on account that both cases had high (around 97\%) injectability percentages (Fig. 5b). Despite injectability decreases slightly when fibroin concentration increases, it is not enough to establish differences between the concentration and the assessed factor. In addition, we observed material waste in the needle and syringe walls at the end of the trial, even though the plunger reached its stop; this can result in mass differences before and after the injection, and therefore, we conclude that the material is completely injectable. 

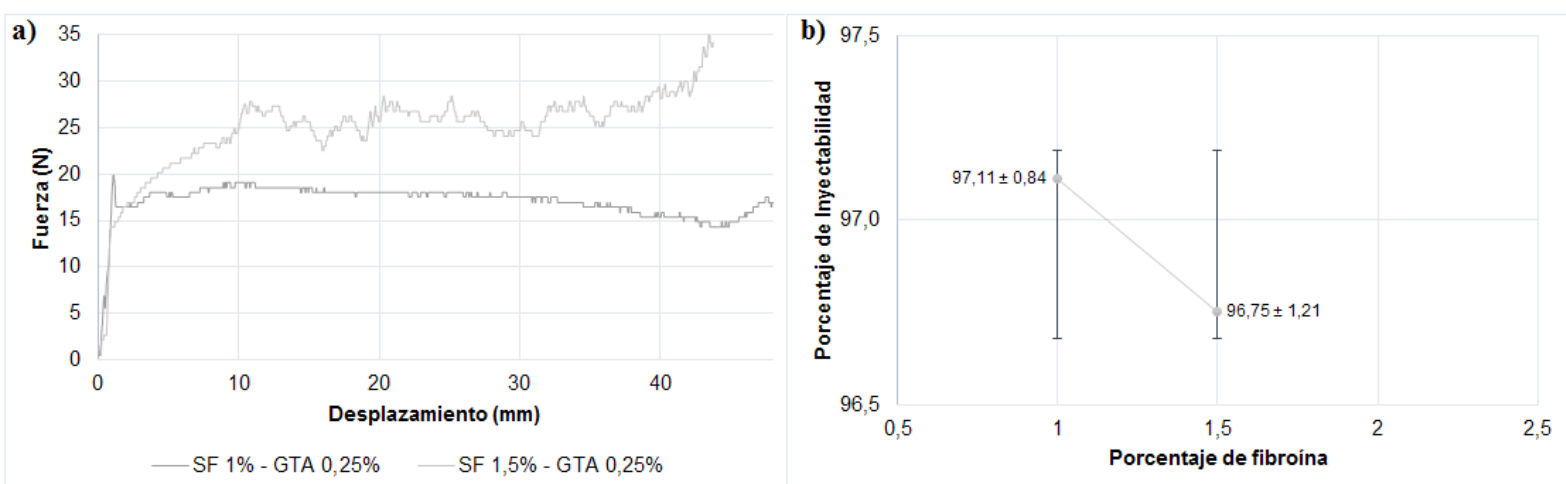

FIG. 5. a) Injectability force versus displacement curve, b) injectability rates for injectable bone substitutes SF/nHA.

The values obtained for compressive strength indicate that the material is weak when deformed (Table 1); however, it should be noted that the test was only performed up to $75 \%$ deformation from the initial height of the specimen, due to the moist and soft nature of the materials manufactured. These materials can continue increasing the exertion with the increase in deformation; the elastic modulus corroborated the above and their values indicate that the material is very soft. We expected this result for this type of material due to the large quantity of solids dispersed in an aqueous polymeric solution that functions as a vehicle for the particles. Additionally, the mechanical properties decreased as the fibroin concentration increased; this may be due to the fibroin solution used, since at a lower concentration there is more water inside the material, and therefore, greater predominance and expression of the solid component $(60 \% \mathrm{HA})$ that has a ceramic nature and better behavior against compression. The amount of GTA used involves a cross-linking with fibroin and, therefore, a better stabilization of the polymer, which is why the HA particles integrate better into the polymer solution decreasing the mechanical properties. The compressive strength and the elastic modulus for cortical bone range from 131-229 $\mathrm{MPa}$ and from 3-30 GPa, while for trabecular bone range from 5-30 MPa and from 0.02-17 MPa, respectively [51-54]. Although our values of the mechanical properties were lower to those reported for bone, it is important to emphasize that since the main potential application of the material is for filling bone cavities, we expect to see an increase in these properties once implanted, due to cellular colonization and the HA calcification and new bone formation $[53,55]$.

\section{TABLE 1}

BONE SUBSTITUTE AND MECHANICAL PROPERTIES

\begin{tabular}{|c|c|c|}
\hline Composition & Compressive strength (MPa) & Elastic modulus (MPa) \\
\hline SF 1\% - GTA 0.25\% & $0.156 \pm 0.031$ & $0.073 \pm 0.022$ \\
\hline SF 1.5\% - GTA 0.25\% & $0.112 \pm 0.012$ & $0.044 \pm 0.011$ \\
\hline
\end{tabular}

\section{Conclusions}

The sintered hydroxyapatite resembled the mineral component of human bone, showing typical characteristics of a stoichiometric hydroxyapatite, in terms of phase stabilization, $\mathrm{Ca} / \mathrm{P}$ ratio and nanorod morphology. Silk fibroin extracted from the cocoons of Bombyx mori showed the appropriate characteristics in the IR tests and molecular weight, making the process suitable to obtain a material that can be used for medical applications.
Injectable bone substitutes showed good degradation and water uptake properties due to the high percentage of HA, which provides chemical stability over time, with low percentages of degradation and water uptake, giving an idea of the material's behavior after implantation. However, these properties depend on the fibroin extraction batch. The fibroin is a vehicle for particle movement that facilitates the manual injection of the substitutes. Although the mechanical resistance is considered low for bone applications, this is not a negative result since the soft and moist nature of the material is what makes the substitute injectable. Moreover, once the substitute is implanted, 
its mechanical properties should improve because of the cellular activity and the subsequent bone formation produced by the amount of HA present, which is a similar to that of the bones.

\section{ACKNOWLEDGeMents}

The authors thank the Universidad de Antioquia, the Biomaterials Research Group Biomat, Professor Carlos Muskus and the doctoral student Didier Enrique Tirado from the Tropical Disease Study and Control Program (PECET) and Colciencias with the 111571552082, CT 257-2016 project.

\section{REFERENCES}

[1] B. F. Ricciardi, and M. P. Bostrom, "Bone graft substitutes: Claims and credibility," Semin. Arthroplasty, vol. 24 (2), pp. 119-123, Jun. 2013. DOI: https://doi.org/10.1053/j.sart.2013.07.002.

[2] A. Hokugo, T. Saito, A. Li, K. Sato, Y. Tabata, and R. Jarrahy, "Stimulation of bone regeneration following the controlled release of water-insoluble oxysterol from biodegradable hydrogel," Biomaterials, vol. 35(21), pp. 5565-71, Jul. 2014. DOI: https://doi. org/10.1016/j.biomaterials.2014.03.018.

[3] K. Lee, et al., "Bone regeneration via novel macroporous CPC scaffolds in critical-sized cranial defects in rats," Dent. Mater., vol. 30(7), pp. e199207, Jul. 2014. DOI: https://doi.org/10.1016/j. dental.2014.03.008.

[4] M. D'Este, and D. Eglin, "Hydrogels in calcium phosphate moldable and injectable bone substitutes: Sticky excipients or advanced 3-D carriers?," Acta Biomater, vol. 9(3), pp. 5421-5430, Mar. 2013. DOI: https://doi.org/10.1016/j.actbio.2012.11.022.

[5] D. S. Morais, et al., "Development and characterization of novel alginate-based hydrogels as vehicles for bone substitutes.," Carbohydr. Polym., vol. 95(1), pp. 134-42, Jun. 2013. DOI: https://doi. org/10.1016/j.carbpol.2013.02.067.

[6] Z. Chen, et al., "Degradability of injectable calcium sulfate/mineralized collagen-based bone repair material and its effect on bone tissue regeneration," Mater. Sci. Eng. C, vol. 45, pp. 94-102, Dec. 2014. DOI: https://doi.org/10.1016/j.msec.2014.08.060.

[7] T. Kokubo (Ed.), Bioceramics and their clinical applications. Boston, USA: JMM, 2008.

[8] J. Wasiak, A. K. Richmond, and B. Sc, "Bone Grafts and Bone Substitutes for Opening-Wedge Osteotomies of the Knee: A Systematic Review," Arthrosc. J. Arthrosc. Relat. Surg., pp. 1-11, 2015.

[9] R. A. Bhatt, and T. D. Rozental, "Bone Graft Substitutes," Hand Clin., vol. 28(4), pp. 457-
468, Nov. 2012. DOI: https://doi.org/10.1016/j. hcl.2012.08.001.

[10] S. Larsson, and G. Hannink, "Injectable bone-graft substitutes: Current products, their characteristics and indications, and new developments," Injury, vol. 42(SUPPL. 2), pp. S30-S34, Sep. 2011. DOI: https:// doi.org/10.1016/j.injury.2011.06.013.

[11] I. M. Pelin, S. S. Maier, G. C. Chitanu, and V. Bulacovschi, "Preparation and characterization of a hydroxyapatite-collagen composite as component for injectable bone substitute," Mater. Sci. Eng. C, vol. 29(7), pp. 2188-2194, Aug. 2009. DOI: https:// doi.org/10.1016/j.msec.2009.04.021.

[12] J. Melke, S. Midha, S. Ghosh, K. Ito, and S. Hofmann, "Silk fibroin as biomaterial for bone tissue engineering," Acta Biomater, vol. 31, pp. 1-16, Feb. 2016. DOI: https://doi.org/10.1016/j. actbio.2015.09.005.

[13] M. Sadat-Shojai, M.-T. Khorasani, E. DinpanahKhoshdargi, and A. Jamshidi, "Synthesis methods for nanosized hydroxyapatite with diverse structures.," Acta Biomater, vol. 9(8), pp. 7591-621, Aug. 2013. DOI: https://doi.org/10.1016/j.actbio.2013.04.012.

[14] B. Kundu, R. Rajkhowa, S. C. Kundu, and X. Wang, "Silk fibroin biomaterials for tissue regenerations," Adv. Drug Deliv. Rev., vol. 65(4), pp. 457-470, Apr. 2013. DOI: https://doi.org/10.1016/j. addr.2012.09.043.

[15] L.-D. Koh, et al., "Structures, Mechanical Properties and Applications of Silk Fibroin Materials," Prog. Polym. Sci., pp. 1-25, 2015. DOI: https://doi. org/10.1016/j.progpolymsci.2015.02.001.

[16] M. Buitrago, "Síntesis de nanofibras de fosfatos de calcio para su posible uso en sustitutos óseos," Thesis, Bioingeniera, Universidad de Antioquia, 2014.

[17] J. Hu, et al., "Injectable silk fibroin/polyurethane composite hydrogel for nucleus pulposus replacement," J. Mater. Sci. Mater. Med., vol. 23(3), pp. 711-722, Mar. 2012. DOI: https://doi. org/10.1007/s10856-011-4533-y.

[18] P. Wang, B. Pi, J.-N. Wang, X.-S. Zhu, and H.L. Yang, "Preparation and properties of calcium sulfate bone cement incorporated with silk fibroin and Sema3A-loaded chitosan microspheres," Front. Mater. Sci., vol. 9(1), pp. 51-65, Mar. 2015. DOI: https://doi.org/10.1007/s11706-015-0278-8.

[19] M. A. de Moraes, G. M. Nogueira, R. F. Weska, and M. M. Beppu, "Preparation and characterization of insoluble silk fibroin/chitosan blend films," Polymers (Basel)., vol. 2(4), pp. 719-727, Dec. 2010. DOI: https://doi.org/10.3390/polym2040719.

[20] J. Jin, et al., "Transplantation of human placentaderived mesenchymal stem cells in a silk fibroin/ hydroxyapatite scaffold improves bone repair in rabbits," J. Biosci. Bioeng., vol. 118(5), pp. 593- 
598, Nov. 2014. DOI: https://doi.org/10.1016/j. jbiosc.2014.05.001.

[21] M. Ribeiro et al., "Development of silk fibroin/ nanohydroxyapatite composite hydrogels for bone tissue engineering," Eur. Polym. J., vol. 67, pp. 66-77, Jun. 2015. DOI: https://doi.org/10.1016/j. eurpolymj.2015.03.056.

[22] S. Ghanaati, et al., "An injectable bone substitute composed of beta-tricalcium phosphate granules, methylcellulose and hyaluronic acid inhibits connective tissue influx into its implantation bed in vivo," Acta Biomater, vol. 7(11), pp. 40184028, Nov. 2011. DOI: https://doi.org/10.1016/j. actbio.2011.07.003.

[23] C. Cao, H. Li, J. Li, C. Liu, H. Yang, and B. Li, "Mechanical reinforcement of injectable calcium phosphate cement/silk fibroin (SF) composite by mineralized SF," Ceram. Int., vol. 40(9), PART A, pp. 13987-13993, Nov. 2014. DOI: https://doi. org/10.1016/j.ceramint.2014.05.123.

[24] J. Hu, X. Cai, S. Mo, L. Chen, X. Shen, and H. Tong, "Fabrication and characterization of chitosansilk fibroin/hydroxyapatite composites via in situ precipitation for bone tissue engineering," Chinese J. Polym. Sci., vol. 33(12), pp. 1661-1671, Dec. 2015. DOI: https://doi.org/10.1007/s10118-015-1710-3.

[25] L. Chen, J. Hu, J. Ran, X. Shen, and H. Tong, "Preparation and evaluation of collagen-silk fibroin/ hydroxyapatite nanocomposites for bone tissue engineering," Int. J. Biol. Macromol., vol. 65, pp. 1-7, Apr. 2014. DOI: https://doi.org/10.1016/j. ijbiomac.2014.01.003.

[26] ASTM International, "Standard Practice for In-Vitro Environmental Conditioning of Polymer Matrix Composite Materials and Implant Devices.” 2008.

[27] T. Kokubo, and H. Takadama, "How useful is SBF in predicting in vivo bone bioactivity?," Biomaterials, vol. 27(15), pp. 2907-2915, May. 2006. DOI: https:// doi.org/10.1016/j.biomaterials.2006.01.017.

[28] R. Silva, et al., "Soft-matrices based on silk fibroin and alginate for tissue engineering," Int. J. Biol. Macromol., vol. 93, pp. 1420-1431, Dec. 2016. DOI: https://doi.org/10.1016/j.ijbiomac.2016.04.045.

[29] H. G. Oliveira Barud, et al., "Preparation and characterization of a bacterial cellulose/silk fibroin sponge scaffold for tissue regeneration," Carbohydr. Polym., vol. 128, pp. 41-51, Sep. 2015. DOI: https:// doi.org/10.1016/j.carbpol.2015.04.007.

[30] H. H. K. Xu, M. D. Weir, E. F. Burguera, and A. M. Fraser, "Injectable and macroporous calcium phosphate cement scaffold," Biomaterials, vol. 27(24), pp. 4279-4287, Aug. 2006. DOI: https://doi. org/10.1016/j.biomaterials.2006.03.001.

[31] E. F. Burguera, H. H. K. Xu, and L. Sun, "Injectable Calcium Phosphate Cement: Effects of Powder to Liquid Ratio and Needle Size," vol. 84(2), pp. 493502, 2009.
[32] J. Liu, J. Li, J. Ye, and F. He, "Setting behavior, mechanical property and biocompatibility of antiwashout wollastonite/calcium phosphate composite cement," Ceram. Int., vol. 42(12), pp. 13670 13681, Sep. 2016. DOI: https://doi.org/10.1016/j. ceramint.2016.05.165.

[33] ASTM International, Standard Test Method for Monotonic Compressive Strength of Advanced Ceramics at Ambient Temperature. 2014.

[34] M. Sadat-Shojai, M. T. Khorasani, and A. Jamshidi, "Hydrothermal processing of hydroxyapatite nanoparticles - A Taguchi experimental design approach," J. Cryst. Growth, vol. 361(1), pp. 73-84, Dec. 2012. DOI: https://doi.org/10.1016/j. jcrysgro.2012.09.010.

[35] X.-Y. Zhao, et al., "Hydrothermal synthesis of hydroxyapatite nanorods using pyridoxal-5' phosphate as a phosphorus source," Mater. Res. Bull., vol. 55, pp. 67-70, Jul. 2014. DOI: https://doi. org/10.1016/j.materresbull.2014.04.008.

[36] S. K. Padmanabhan, A. Balakrishnan, M.-C. Chu, Y. J. Lee, T. N. Kim, and S.-J. Cho, "Sol-gel synthesis and characterization of hydroxyapatite nanorods," Particuology, vol. 7(6), pp. 466-470, Dec. 2009. DOI: https://doi.org/10.1016/j.partic.2009.06.008.

[37] Y. Liu, et al., "Long-term biodistribution in vivo and toxicity of radioactive/magnetic hydroxyapatite nanorods.," Biomaterials, vol. 35(10), pp. 334855, Mar. 2014. DOI: https://doi.org/10.1016/j. biomaterials.2013.12.064.

[38] W. P. S. L. Wijesinghe, et al., "Facile synthesis of both needle-like and spherical hydroxyapatite nanoparticles: Effect of synthetic temperature and calcination on morphology, crystallite size and crystallinity," Mater. Sci. Eng. C, vol. 42, pp. 83-90, Sep. 2014. DOI: https://doi.org/10.1016/j. msec.2014.05.032.

[39] S. C. Medoza Ruiz, and E. Delgado Mejía, "Propuesta y evaluación de una síntesis rápida y selectiva de algunos fosfatos de calcio por el método ácido-base," Universidad Nacional de Colombia, 2005.

[40] ASTM International, "Standard Specification for Composition of Ceramic Hydroxyapatite for Surgical Implants," F1185-88. 2014.

[41] Y. Cheng, L. Koh, D. Li, B. Ji, M. Han, and Y. Zhang, "On the strength of $\beta$-sheet crystallites of Bombyx mori silk fibroin," Interface, vol. 11, 2014.

[42] S. Xiao, Z. Wang, H. Ma, H. Yang, and W. Xu, "Effective removal of dyes from aqueous solution using ultrafine silk fibroin powder," Adv. Powder Technol., vol. 25(2), pp. 574-581, Mar. 2014. DOI: https://doi.org/10.1016/j.apt.2013.09.007.

[43] A. Teimouri, M. Azadi, R. Emadi, J. Lari, and A. N. Chermahini, "Preparation, characterization, degradation and biocompatibility of different silk fibroin based composite scaffolds prepared by freeze-drying method for tissue engineering 
Degradation, water uptake, injectability and mechanical strength of injectable bone substitutes composed of silk fibroin and hụdroxyapatite nanorods

application," Polym. Degrad. Stab., vol. 121, pp. 18-29, Nov. 2015. DOI: https://doi.org/10.1016/j. polymdegradstab.2015.08.004.

[44] D. M. Zeng, J. J. Pan, Q. Wang, X. F. Liu, H. Wang, and K. Q. Zhang, "Controlling silk fibroin microspheres via molecular weight distribution," Mater. Sci. Eng. C, vol. 50, pp. 226-233, May. 2015. DOI: https://doi.org/10.1016/j.msec.2015.02.005.

[45] Q. Liu, Z. Chen, H. Pan, and B. W. Darvell, "The effect of excess phosphate on the solubility of hydroxyapatite," Ceram. Int., vol. 40(2), pp. 27512761, Mar. 2014. DOI: https://doi.org/10.1016/j. ceramint.2013.10.044.

[46] M. Andiappan, et al., "Electrospun eri silk fibroin scaffold coated with hydroxyapatite for bone tissue engineering applications," Prog. Biomater, vol. 2(1), p. 6, 2013. DOI: https://doi.org/10.1186/2194-0517$2-6$.

[47] Z. Hadisi, J. Nourmohammadi, and J. Mohammadi, "Composite of porous starch-silk fibroin nanofibercalcium phosphate for bone regeneration," Ceram. Int., vol. 41(9), pp. 10745-10754, Nov. 2015. DOI: https://doi.org/10.1016/j.ceramint.2015.05.010.

[48] G. Daculsi, "History of Development and Use of the Bioceramics and Biocomposites," in Handbook of bioceramics and biocomposites, I. V. Antoniac, Ed. Rumania: Springer, 2016, pp. 1-1386.

[49] U. J. Kim, J. Park, H. Joo Kim, M. Wada, and D. L. Kaplan, "Three-dimensional aqueous-derived biomaterial scaffolds from silk fibroin," Biomaterials, vol. 26(15), pp. 2775-2785, May. 2005. DOI: https:// doi.org/10.1016/j.biomaterials.2004.07.044.

[50] M. P. Ginebra, A. Rilliard, E. Fernández, C. Elvira, J. San Román, and J. A. Planell, "Mechanical and rheological improvement of a calcium phosphate cement by the addition of a polymeric drug," J. Biomed. Mater. Res., vol. 57(1), pp. 113-118, Oct. 2001. DOI: https://doi. org/10.1002/1097-4636(200110)57:1<113::AIDJBM1149>3.0.CO;2-5.

[51] M. Nordin and V. H. Frankel, Basic Biomechanics of the Musculoeskeletal System, 3rd ed. Lippincott Williams and Wilkins, 2001.

[52] M. E. Navarro Toro, "Desarrollo y caracterización de materiales biodegradables para regeneración ósea," Doctoral Thesis, Universidad Politécnica de Catalunya, 2005.

[53] J. González Ocampo, "Evaluación de las propiedades de cuerpos porosos de hidroxiapatita, obtenidos por gel-casting y su infiltración en espumas poliméricas," Master Thesis, Universidad de Antioquia, 2013.

[54] J. Black, and G. Hastings, Handbook of Biomaterial Properties. Boston: Chapman \& Hall, 1998. DOI: https://doi.org/10.1007/978-1-4615-5801-9.

[55] G. Tripathi, and B. Basu, "A porous hydroxyapatite scaffold for bone tissue engineering: Physicomechanical and biological evaluations," Ceram. Int., vol. 38(1), pp. 341-349, Jan. 2012. DOI: https://doi. org/10.1016/j.ceramint.2011.07.012. 